\title{
Learning Media Development Based on "Meme" as Efforts to Prevent Miscellanee Drug Abuse in Class VI of Elementary School
}

\author{
Farihah, Faisal \\ Medan State University \\ Medan, Indonesia \\ Email: farihah34@gmail.com
}

\begin{abstract}
This study aims to develop meme-based learning media as an effort to prevent early drug abuse in grade VI of elementary school. This research uses 4-D model, namely: defining, designing, developing, and disseminating. There are three main activities undertaken when developing meme-based learning media, namely: the test of validity, practicality, and effectiveness. The results show that the development of memebased learning media has been declared valid, practical, and effective use in class VI of elementary school. Thus, meme-based learning media can be considered as an effort to prevent early drug abuse in grade VI of elementary school.
\end{abstract}

Keywords: meme, drugs, validity, practicality, effectiveness, elementary school

\section{INTRODUCTION}

One of the things that have always been a problem in society and needs special attention is drug abuse. Initially, drug use was limited to medicine. However, lately, there is a deviation of function and its use is no longer limited to the medical world. The use of various types of drugs and addictive substances or commonly called drugs today is quite increasing, especially among the younger generation. Morphine and similar drugs originally used as a painkiller have long been abused. Healthy people are not a few who consume these drugs. Rampant circulation and abuse of narcotics and illegal drugs are widely recognized and become a dangerous threat to the Indonesian nation.

Based on the results of the National Narcotics Agency survey related drug use recorded as many as 921,695 people or approximately 4.7 percent of the total students and students in the country as a user of illicit goods. The study also showed the increasing age of drug abuse, with the youngest being 7 years old. Added also that the type of drugs that are often used is inhaled. Meanwhile, at the age of 8 years, there are already using marijuana and the age of 10 years has been using drugs with a variety of types, namely sedative, marijuana, and morphine.

Among the students today, especially for those who are formally at school generally use the first drug started in elementary school children or junior high school. This happens usually because of the offer, persuasion, or pressure of a person or group of people to him, for example by his peers. Other causes can be prolonged stress, lack of parental attention, household cracks/broken home, and simultaneously driven curiosity, want to try or want to wear, someone willing to accept the offer. Furthermore, it is not difficult for him to accept the next offer so that will cause dependence on drugs that are used.

In response to what has been mentioned above, special attention should be given early on to the students, especially for elementary school students. Teachers can make various efforts in preventing drug abuse for elementary school students, one of them by developing learning media. Learning media developed can be an invitation-related to the dangers of drug abuse. It should be noted that the invitation should involve characters deemed capable of influencing elementary school students, such as inspiring national figures, idol figures, and the people around who are considered influential. However, the difficulty of meeting directly with the characters in question makes what is expected to be constrained. Therefore, it is necessary to do tactics in developing learning media by still involving various figures who are considered capable of affecting elementary school students.

One of the efforts that can be done is to develop memebased learning media. The Merriam-Webster dictionary defines memes as "an idea, habit or style that spreads from person to person in a culture". The term meme itself was first introduced by a biologist from the United Kingdom, Richard Dawkins. The root is derived from Greek, ie mimesis, which means imitation. Dawkins defines memes as a unit of cultural information (in the form of thoughts, ideas, ideas, habits, songs) that shape certain cultural patterns. He analogizes memes with genes, like those in the human body. Since memes are analogous to genes, we can see that memes have similar characteristics to genes. In his book "The Selfish Gene" explained if the genes breed in the gene pool by jumping from body to body through sperm and egg. Meme breeds in meme ponds by jumping from brain to brain through a process, which, in a broad sense, is called imitation.

Based on the above explanation, it can be concluded that meme is a collection of images collected from television shows (TV), movies, and so forth. The image is then modified by adding words, writings that are assembled with images. Thus, meme-based learning media can provide understanding to students related to drug abuse so as to avoid early. 
Please note that there are three main requirements that must be considered in the development of learning media, namely: the validity, praktikalitas, and the effectiveness of learning media. In relation to validity, Otto (2010: 348) explains that "Validity refers to the notion that the answer actually measures what it is intended to measure. This means that validity refers to the idea that the truly appropriate measure what is meant to be measured. This means that the various tasks are carefully selected to represent important developmental basis and behaviours." Associated with practice, Akker et al (1999: 10) explains that "Practice refers to the intervention as appealing and usable in 'normal' conditions." That is, practicality refers to the degree that the user considers Interventions can be used and preferred under normal conditions. In relation to effectiveness, Akker et al (1999: 10) explains that "Effectiveness references to the extent that the experiences and outcomes with the intervention are consistent with the intended aims." That is, effectiveness refers to the level of experience and outcome of the intervention consistent with the intended purpose. That is the effectiveness of seeing the accuracy and appropriateness of using something with the expected goal so as to provide a meaningful experience for each user.

\section{METHODS}

Meme-based learning media as an effort to prevent early abuse of drugs in grade VI of elementary school was tested in class VI 10 Lembah Melintang State Elementary School with the number of students 24 people as well as conducted the dissemination on a limited scale in the class VI 08 Lembah Melintang State Elementary School with the number 25 students. Instruments used in this study include observation sheets, questionnaires, and interview sheets. Observation sheets record learning activities; Questionnaires to record product assessment data from learning design experts, teachers, and students as product users; Interviews to record the development of students' understanding of drug abuse.

This research is a research development or often called R\&D (Research and Development). The development model used is a 4-D development model (four D models). In this case, Sugiyono (2009:404) explains that there are 4 stages in the 4-D model, among others: define, design, development, and disseminate. Matters relating to the stages described can be seen in Figure 1. The defining stage aims to define and define the learning requirements in accordance with the purpose of research that is the development of meme-based learning media as an effort to prevent drug abuse early in the class VI Primary School. At this stage, the stages of the activities undertaken are 2, namely: needs analysis and characteristic analysis of grade 6 students of Primary School.

The design stage is to design the development of memebased learning media as an effort to prevent early drug abuse in grade VI of elementary school. Things to consider when designing instructional media include (1) suitability of sentences with selected images, (2) grammar used (readability level readability), and (3) ways of presenting materials that influence media development Meme-based learning.

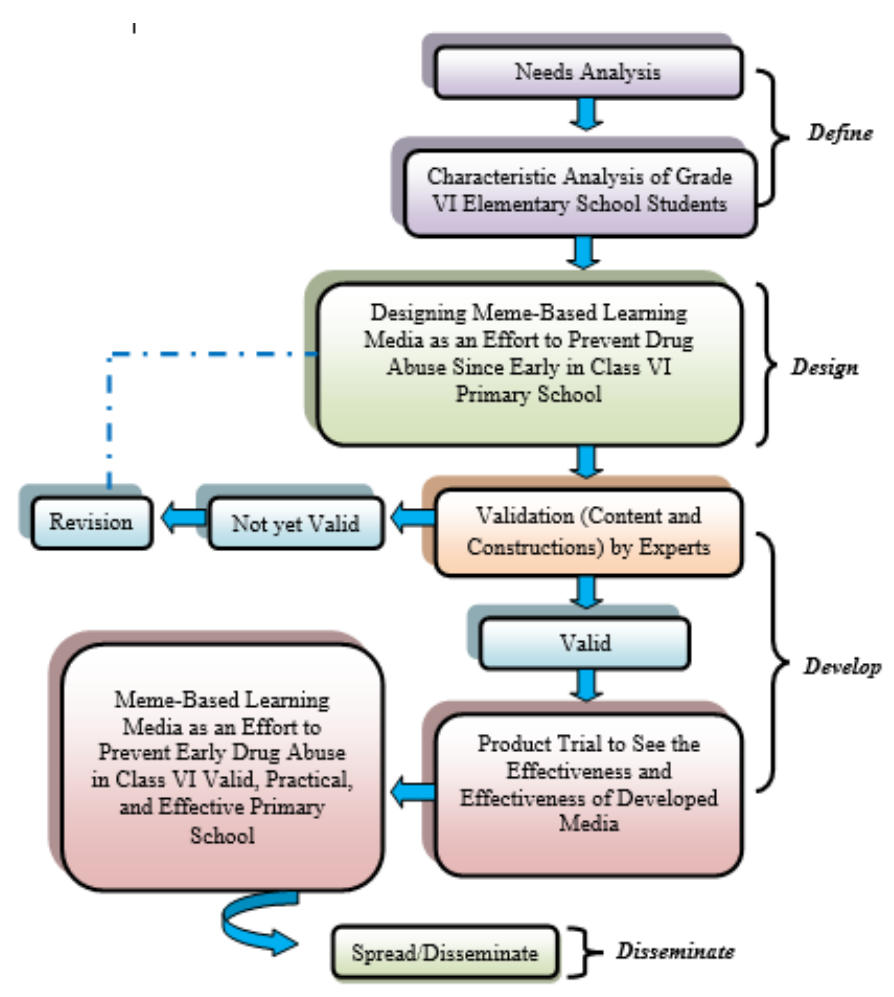

Fig. 1. Memory-Based Memory Development Chart as an Effort to Prevent Drug Abuse Since Early in Class VI Primary School

The purpose of the development stage is to produce a revised learning media based on input from experts. This stage includes product validation by experts aimed at obtaining feedback on the overall package of instructional media developed. If the learning media developed is not valid yet, a revision is made. However, if the learning media is valid, limited trials are conducted to see the practicality or exposure of the learning media that has been produced. Development stage includes validity, practicality, and effectiveness test.

The disseminate stage is the final step of the 4-D step on offer. After being validated and tested by practicability and effectiveness in a certain class obtained valid, practical, and effective learning media. After that, disseminate (disseminate) on a wider scale. It aims to further look at the level of effectiveness of instructional media that has been developed in other class groups. Thus, the exposure of developed learning media is not only appropriate for certain classes but in other classes.

The type of data taken in this study is data validity, practicability, and effectiveness of learning media developed. The results of validity are obtained through the assessment of expert validators. Data obtained for practicality are (1) observation result of learning media from observer, (2) observation result of student activity from observer, (3) student response to instructional media developed after tested, and (4) teacher response to media which was developed after being tested. While the effectiveness data obtained through activities and increased understanding, and student commitment to antidrug. 
The average earned is confirmed by the specified criteria. Widjajanti (2008:58) provides procedures for determining the level of validity with criteria such as Table 1 .

TABLE 1. CRITERIA FOR ESTABLISHING VALIDITY LEVELS

\begin{tabular}{|c|c|}
\hline Range & Category \\
\hline $1,00-1,99$ & Invalid \\
\hline $2,00-2,99$ & Less Valid \\
\hline $3,00-3,49$ & Valid \\
\hline $3,50-4,00$ & Very Valid \\
\hline
\end{tabular}

Practicality analysis is used to cultivate the observed results of instructional media. Similar to validity, the level of practicability is also converted into rubrics scores 1-4. Data of observation result were analyzed using qualitative descriptive statistic with the provision as in Table 2.

TABLE 2. PRACTICALITY PRICING CRITERIA

\begin{tabular}{|c|c|}
\hline Range & Category \\
\hline $1,00-1,99$ & Not Practical \\
\hline $2,00-2,99$ & Less Practical \\
\hline $3,00-3,49$ & Practical \\
\hline $3,50-4,00$ & Very Practical \\
\hline
\end{tabular}

The result data of the students' understanding comprehension were analyzed by percentage calculation using the formula developed from the basic concept of evaluation of learning result (Arikunto, 2006: 233) as follows.

Percentage

$$
\frac{\text { Frequency of student activity performed }}{\text { The }- \text { Number }- \text { of }- \text { student }}
$$

Based on the percentage obtained, the grouping is done according to the criteria stated by Arikunto (2006:166) in Table 3 .

TABLE 3. CRITERIA FOR DETERMINING THE EFFECTIVENESS OF LEARNING MEDIA

\begin{tabular}{|c|c|}
\hline Percentage (\%) & Criteria \\
\hline $81-100$ & Very high \\
\hline $61-80$ & High \\
\hline $41-60$ & Medium \\
\hline $21-40$ & Low \\
\hline $1-20$ & Very low \\
\hline
\end{tabular}

\section{RESULT AND DISCUSSION}

The result of this research is developing meme-based learning media as an effort to prevent early abuse of drugs in class VI primary school that valid, practical, and effective. For more details, can be described as follows.

\section{A. Media Learning Validity}

Plomp (2007:127) states that the characteristics of the lesson are said to be valid when it reflects the knowledge of the state (the state of the art knowledge). This is what is said by content validation. Furthermore, the components of learning tools developed must also be consistent with each other and this is what is said by construct validation. Therefore, validation of meme-based learning media emphasizes content validity and construct validity. Data validation of instructional media from expert validator is presented in Table 4.

\begin{tabular}{|c|c|c|c|}
\hline Number & Rated Aspect & $\begin{array}{c}\text { Validation } \\
\text { Value }\end{array}$ & Category \\
\hline A & Feasibility of Content & 3,67 & Very Valid \\
\hline B & Language & 3,59 & Very Valid \\
\hline $\mathrm{C}$ & Presentation & 3,67 & Very Valid \\
\hline $\mathrm{D}$ & Graphics & 3,42 & Valid \\
\hline \multicolumn{2}{|r|}{ Average } & 3,60 & Very Valid \\
\hline
\end{tabular}

TABLE 4. LEARNing Media VALIDATION Results By EXPERT VALIDATOR

The results of the validation of instructional media assessed by experts in table 4 above, obtained that the average validation results, in general, is 3.60 with the category is very valid. Based on the aspects considered to be obtained the following picture: the feasibility of content 3.67, language 3.59, presentation 3.67, and dish kegrafikaan 3.42. Based on the evaluation of the assessment, it shows that the developed learning media is valid. This means that the media developed is good and can be used as a learning resource for students in efforts to prevent drug abuse early in class VI primary school.

\section{B. Media Learning Practicality}

Plomp (2007:127) explains that a learning medium is said to be practical if learning tools can be used easily by teachers and students in the learning process. To see learning media that is developed practically or not conducted a test on grade VI students of Elementary School of 10 Lembah Melintang of West Pasaman Regency.

The result of observation of media usage at the stage of practicality is the level of ease of students understand the media developed. There are several aspects observed when students observe the media, among others: (a) students readily understand the various concepts of existing learning media and (b) students are interested and motivated to learn from the design of instructional media being displayed.

The results of observation on the ease of students understand the various concepts that exist in the media seen when students observe and read meme text on learning media. Students do not have significant constraints in understanding concepts. Aspects of interest and enthusiasm of students to the media can be observed from the interest of students observing the media given learning. Students look happy to follow the various activities that exist in the media learning. Based on this, it can be concluded that students feel easy to understand the concept and do various tasks that exist in the media learning. Thus, the students did not have any constraints which meant understanding the given learning medium.

Interviews conducted in this study using unstructured interviews, meaning that the question develops according to the respondent's answer (teacher) when asked the question. Media use interviews were conducted on teachers and students. This is done to obtain information related to the level of media exposure developed. Based on the results of interviews with teachers and students, it can be concluded that the use of learning media is quite easy to use in learning. In addition, the 
design of colour and layout can be enough to attract students to understand the memes that exist in the learning media as a whole.

\section{Media Learning Effectivity}

Learning media expressed valid and practical before the need to be seen effectiveness in the learning process. According to Firman (2010:56), the effectiveness of a learning medium is characterized by the following characteristics: (a) succeeds in delivering the students to achieve specified instructional goals, (b) providing an attractive learning experience, involving students actively so as to support The achievement of instructional goals, (c) having the means to support the learning process.

Student activity during the learning activity took place observed by using the instrument of observation of student activity. Detailed observation data are presented in Table 5.

TABLE 5. STUDENT ACTIVITY OBSERVATION RESULTS

\begin{tabular}{|c|c|c|c|}
\hline $\begin{array}{c}\text { Num } \\
\text { ber }\end{array}$ & Rated Aspect & $\begin{array}{c}\text { Percentage } \\
(\boldsymbol{\%})\end{array}$ & Category \\
\hline 1. & $\begin{array}{c}\text { Pay attention and listen to } \\
\text { teacher explanations }\end{array}$ & 91,67 & Very High \\
\hline 2. & $\begin{array}{c}\text { Pay attention to instructional } \\
\text { media }\end{array}$ & 77,08 & High \\
\hline 3. & Asking question & 83,33 & Very High \\
\hline 4. & Respond & 66,67 & High \\
\hline & Average & 79,69 & Very High \\
\hline
\end{tabular}

Table 5 above illustrates that the activity of students when the learning process took place an average of $79.69 \%$ with the high category. It can be said that students are enthusiastic when following the learning process through developed learning media.

Students pay attention and listen well when the teacher explains the material related to the displayed media. This can be seen from the average value obtained from the observation sheet, which is $91.67 \%$ of the very high category. Furthermore, students can ask questions well if there is material that is poorly understood. The average value obtained from observations is $83.33 \%$ with the very high category. However, the responding aspects decreased slightly compared with the previous aspects. Nevertheless, the average obtained based on observations on responding aspects is $66.67 \%$ with the high category. That is, students can respond well although fewer than the other aspects.

Based on the above explanation, gives an idea that the developed learning media can help in increasing student activity. In addition, teachers feel facilitated by the development of learning media. The learning media provides positive suggestions for students to learn, which is indicated on increasing student activity during the learning process takes place. Thus, when viewed from student activities, the media developed has been effectively applied in learning.

\section{IV.CONCLUSIONS}

Based on the development and experimentation of learning media that has been developed, obtained the following conclusions.

1. Meme-based learning media have been produced as an effort to prevent valid drug abuse in Grade VI Primary School. It can be seen based on a validation result of instructional media by the expert validator.

2. Meme-based media has been produced as an effort to prevent the misuse of drugs in the classroom of Primary School VI. This is evident from the teacher and student response, observation, and interviews that have been done.

3. Meme-based learning media have been produced in an effort to prevent effective drug abuse in grade VI of elementary school. The effectiveness of the use of learning media can be known through the observation of student activity. The result of observation of student activity gives a very good result picture, meaning that the use of media in an effort to prevent drug abuse has been effectively implemented in Grade VI of Elementary School.

\section{REFERENCES}

[1] Akker, Jan Van Den, dkk. (1999). Design Approaches and Tools in Education and Training. Dordrecht: Kluwer Academic Publishers.

[2] Arikunto, Suharsimi. (2006). Research Procedure: A Practice Approach. Jakarta: Rineka Cipta.

[3] Dahlan, Desi. (2012). "Development of Learning Tools Based on Quantum Learning Biology on Digestive System Material for Upper School.” Tesis Not Published. Padang: Padang State University.

[4] Firman, Harry. (2010). Assessment of Learning Outcomes in Teaching. Bandung: Indonesian Education University.

[5] Law of the Republic of Indonesia Number 35 The year 2009 on Narcotics.

[6] Law of the Republic of Indonesia Number 35 The year 2014 on Amendment to Law Number 23 The year 2002 Regarding Child Protection.

[7] Otto, Beverly. (2010). Language Development in Early Childhood. USA: Pearson Education.

[8] Plomp, T. dan Nieveen, N. (Eds). (2007). An Introduction to Educational Design Research. Enschede: Netherlands Institute for Curriculum Development (SLO).

[9] Sugiyono. (2009). Educational Research Methods Quantitative, Qualitative, and R \& D. Bandung: Alfabeta.

[10] Widjajanti, E. (2008). "Training of Chemistry Subject Sheet Formation Based on KTSP for Vocational High School Teachers." Paper Presented in Community Service Activities, Department of the Chemistry Education State University of Yogyakarta. 